\title{
Research
}

\section{Mammal Distribution in Nunavut: Inuit Harvest Data and COSEWIC's Species at Risk Assessment Process}

\author{
$\underline{\text { Karen A. Kowalchuk }}^{1}$ and Richard G. Kuhn ${ }^{1}$
}

\begin{abstract}
The Committee on the Status of Endangered Wildlife in Canada (COSEWIC) assesses risk potential for a species by evaluating the best available information from all knowledge sources including Aboriginal traditional knowledge (ATK). Effective application of ATK in this process has been challenging. Inuit knowledge (IK) of mammal distribution in Nunavut is reflected, in part, in the harvest spatial data from two comprehensive studies: the Use and Occupancy Mapping (UOM) Study conducted by the Nunavut Planning Commission (NPC) and the Nunavut Wildlife Harvest Study (WHS) conducted by the Nunavut Wildlife Management Board (NWMB). The geographic range values of extent of occurrence (EO) and area of occupancy (AO) were derived from the harvest data for a selected group of mammals and applied to Phase I of the COSEWIC assessment process. Values falling below threshold values can trigger a potential risk designation of either endangered (EN) or threatened (TH) for the species being assessed. The IK values and status designations were compared with available COSEWIC data. There was little congruency between the two sets of data. We conclude that there are major challenges within the risk assessment process and specifically the calculation of AO that contributed to the disparity in results. Nonetheless, this application illustrated that Inuit harvest data in Nunavut represents a unique and substantial source of ATK that should be used to enrich the knowledge base on arctic mammal distribution and enhance wildlife management and conservation planning.
\end{abstract}

Key Words: Aboriginal traditional knowledge, arctic wildlife, area of occupancy, ATK, Committee on the Status of Endangered Wildlife in Canada, COSEWIC, extent of occurrence, geographic distribution, harvest data, Inuit knowledge, Nunavut, species at risk

\section{INTRODUCTION}

Critical decision making protocols guide conservation and protection strategies for wildlife in Canada. The best available information on a species is required from scientific and traditional knowledge sources including Aboriginal traditional knowledge (ATK; see the Appendix 1 for Glossary of Acronyms). The Committee on the Status of Endangered Wildlife in Canada (COSEWIC) is responsible for the assessment of wildlife species at risk and for recommending a species designation to the Government of Canada where programs and strategies are implemented through the federal Species at Risk Act of 2002 (SARA; Government of Canada 2002). In this research, mammal distribution values derived from Inuit harvest sites in Nunavut were used as ATK within the COSEWIC assessment process to explore the potential application of this knowledge source. Harvest data were collected through two comprehensive surveys undertaken throughout Nunavut between 1996 and 2010.

\section{BACKGROUND}

The COSEWIC assessment process is defined by three sequential steps; identification of candidate wildlife species; compilation of the best available information of the species in a status report; and status assessment of a species' risk and assignment of status designation (COSEWIC 2010a). The COSEWIC Status Report is a technical report prepared by experts that includes current information on history, habitat, sizes, and trends in population, geographic distribution, and potential threats (COSEWIC 2011a). Data from status reports are used in the COSEWIC assessment process to determine a designation of endangered (EN), threatened (TH), not at risk (NAR), or data deficient (DD). The suggested status is then evaluated within additional contextual considerations that may be used to modify the initial assessment, including to a special concern (SC) designation (COSEWIC 2010a).

The criteria used in COSEWIC's assessment process are based on the revised International Union of Conservation of Nature (IUCN) Red List categories (IUCN 2001). The process occurs in two phases. Phase I addresses five quantitative criteria whereas Phase II is based on four modifying criteria (Fig. 1). Values applied to Phase I are obtained from the species status report. These values may reflect the entire species or those of a designatable unit (DU), which is a distinct population affected by different trends or environmental factors that has clear genetic or historical distinctions and/or "discrete and evolutionarily significant" attributes (COSEWIC 2011b). Any value applied to any of the five criteria in Phase I (A through E) can trigger a potential risk designation of endangered or threatened if that value falls below the threshold values used by COSEWIC.

The quantitative criteria within Section B of Phase I focus on the size of the geographic distribution of the species being assessed as measured by the extent of occurrence and the area of occupancy (Fig. 2). The extent of occurrence (EO) is the spatial or geographic spread of a species and broadly 
encompasses all known point locations of that species, including some areas that are either unsuitable or uncolonized (Gaston 1994, Goehring et al. 2007, Hurlbert and Jetz 2007, Boitani et al. 2008, COSEWIC 2011a). It is a general metric used to measure the degree of risk from threatening factors including large-scale or ecosystem processes that can limit a species range. The larger the value, the less the likelihood of impact on all areas simultaneously, i.e., the lower the extinction risk (Gaston and Fuller 2009).

Fig. 1. Summary of Committee on the Status of Endangered Wildlife in Canada (COSEWIC) quantitative and modifying criteria (Based on Lukey and Crawford 2009:960, used with permission). See Appendix 1 for glossary of acronyms.

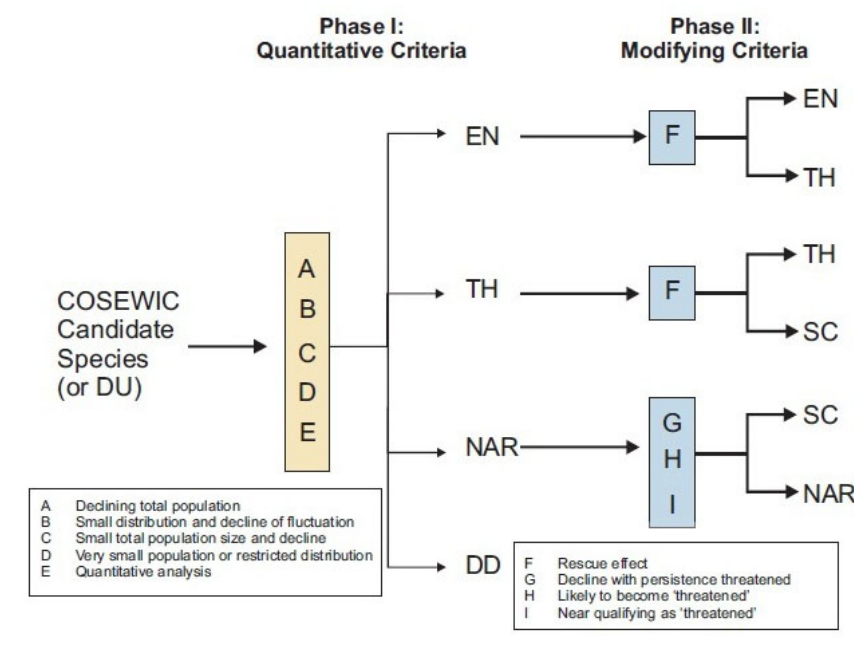

The area of occupancy (AO) represents the actual amount of habitat utilized by a species for breeding, feeding, and other essential biophysical processes. It is almost always significantly smaller than the EO. The AO can play a critical role in conservation planning in conjunction with population numbers, fragmentation patterns, and identification of patches, connections, or corridors (Goehring et al. 2007, Boitani et al. 2008).

During assessment and categorization, the geographic range values of EO and $\mathrm{AO}$ for a species, if available, are compared with COSEWIC set threshold values. Values that fall below COSEWIC threshold values can trigger a potential status designation of either threatened (TH) or endangered (EN). These values are viewed in conjunction with fragmentation and continuing decline of information if available. For example, the small, isolated Atlantic-Gaspesie population of woodland caribou (Rangifer tarandus) has an EO value of approximately $1000 \mathrm{~km}^{2}$ that falls below the COSEWIC EO endangered threshold value of $5000 \mathrm{~km}^{2}$ (COSEWIC 2002). This DU is designated as "endangered".
Fig. 2. Committee on the Status of Endangered Wildlife in Canada (COSEWIC) quantitative assessment criteria: Phase I Section B (COSEWIC 2010a:9).

\begin{tabular}{|c|c|c|}
\hline Indicator & Endangered & Threatened \\
\hline \multicolumn{3}{|l|}{ B. Small Distribution Range and Decline or Fluctuation } \\
\hline B1. Extent of occurrence (EO) estimated to be & $<5,000 \mathrm{~km}^{2}$ & $<20,000 \mathrm{~km}^{2}$ \\
\hline $\begin{array}{l}\text { B2. Index of area of occupancy (IAO) estimated to be and for either } \\
\text { B1 or B2 estimates indicating at least two of a-c: }\end{array}$ & $<500 \mathrm{~km}^{2}$ & $<2,000 \mathrm{~km}^{2}$ \\
\hline (a) Either severely fragmented or known to exist at: & $\leq 5$ locations & $\leq 10$ locations \\
\hline 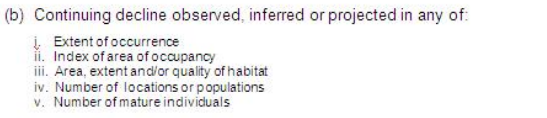 & & \\
\hline $\begin{array}{l}\text { (c) Extreme fluctuations in one or more of the following: } \\
\text { i. Extent of occurrence } \\
\text { il. Index of area of oceupancy } \\
\text { iii. Number of locations orpopulations } \\
\text { iv. Number of mature individuals }\end{array}$ & & \\
\hline
\end{tabular}

Data compiled for COSEWIC Status Reports must be the best available from both scientific and Aboriginal traditional knowledge (ATK) sources (COSEWIC 2011a). The term ATK is utilized by COSEWIC but is also referred to as TEK (traditional ecological knowledge), which has been defined and categorized in numerous publications (e.g., Duerden and Kuhn 1998, Wenzel 1999, Berkes et al. 2000, Usher 2000, Houde 2007). TEK "refers specifically to all types of knowledge about the environment derived from the experience and traditions of a particular group of people" (Usher 2000:185; emphasis in the original). TEK is a broad system of understanding that reflects a shared system of values and is based on observation in situ, over time. Empirical, factual, and specific observations such as geographic locations, e.g., habitation, cultural and harvest sites, are vital attributes. COSEWIC has identified "wildlife species occurrence" and "wildlife species distribution" as components of ATK (COSEWIC 2011a:5). ATK is mandated to be included in status reports when it is available and with guidance from COSEWIC's ATK Subcommittee. The process and protocol guidelines for facilitation of ATK into status reports were approved in 2010 (COSEWIC 2010b).

Historically, there has been limited success including TEK (ATK) in scientific research and wildlife management (e.g., Agrawal 1995, Duerden and Kuhn 1998, Usher 2000, Bala and Joseph 2007). The process of incorporating or integrating TEK in resource management has been thoroughly scrutinized and criticized. Some suggest that TEK is being scientized for western consumption (Simpson 2001a, 2004, Brook and McLachlan 2005, Ellis 2005) or seriously distorted by compartmentalizing and distilling TEK to feed into a EuroCanadian context (Nadasdy 1999). Others adopt the perspective that TEK and western science (WSK) combinations, knowledge, and methods can maximize 
management effectiveness while allowing a critical evaluation of each source (Wenzel 1999, Moller et al. 2004, Gilchrist et al. 2005, Gilchrist and Mallory 2007). There is also widespread recognition that TEK can be misappropriated when TEK research products are tailored for non-Aboriginal agendas. Conflicting agendas, communication barriers, and conceptual and political differences between Aboriginal communities and those conducting TEK research can contribute to the power imbalance and potential marginalization (Kuhn and Duerden 1996, Nadasdy 1999, Simpson 2001b, Brook and McLachlan 2005, Ellis 2005, Nadasdy 2005).

Comanagement of wildlife is evolving to address the challenges of TEK and WSK working in tandem by recognizing the need for cooperative frameworks that include participants conversant in both knowledge sources within an equal and parallel partnership (Armitage 2005, Manseau et al. 2005, Omura 2005, Berkes et al. 2007, Dowsley 2009). A critical feature of such a framework is ideally a culturally aware and respectful relationship that facilitates Aboriginal participation and supports TEK use in decision making processes, rather than as support for WSK assumptions (Kruse et al. 1998, Wenzel 1999, Nadasdy 2005, Natcher et al. 2005).

Integration of Inuit knowledge (IK) into wildlife management is mandated in the Nunavut Land Claims Agreement (Government of Canada 1993) through the creation of the Nunavut Wildlife Management Board (NWMB). One of the functions of the NWMB is to address matters pertaining to the federal Species at Risk Act (SARA) by contributing to the preparation of reports, evaluations, and recommendations for species potentially at risk within the Nunavut territory. This specifically includes collaboration with COSEWIC and potential contributions to the preparation of status reports. Wildlife management initiatives in Nunavut almost always involve hunting and harvesting regulations. In the case of recovery strategies for species at risk, they can include reductions and/or restrictions in quotas. These initiatives have direct implications for Inuit families and communities.

Spatial data documenting Inuit harvest locations have recently been recorded in two major studies in Nunavut: the Use and Occupancy Mapping (UOM) Study conducted by the Nunavut Planning Commission (NPC) from 2004 through 2010, and the Nunavut Wildlife Harvest Study (WHS) conducted by the NWMB from 1996 to 2001.

The UOM Study developed composite maps generated by community knowledge for land use planning and resource management (Tobias 2009). This data collection process also captured some of the oral history and traditional knowledge of Aboriginal people and contributed to the greater ecological knowledge of wildlife and other natural systems. Information on traditional, individual lifetime, and community use of water and land resources was mapped through detailed interviews with community members. Interviewers documented activities within a living memory time frame and created map biographies. Seventy features were recorded as points, lines, or polygons and included animal and plant harvest sites; occupancy sites, i.e., cabins, tents, igloos; sites of life events, i.e., births, deaths, burials; and cultural sites, i.e., sacred areas, landforms. Between 1 and 15 maps $(1: 250,000)$ were generated by each of the approximately 500 participants from all 25 communities in the Territory with an average of six or seven maps each. This rich dataset reflects land use spanning approximately 75 years.

The Wildlife Harvest Study (WHS) documented Inuit hunting numbers and patterns. The objective was to compile a comprehensive set of harvesting data from Inuit hunters in Nunavut to determine harvest levels (total allowable harvest) and to calculate basic needs levels. The data were also collected to "contribute to the sound management and rational utilization of wildlife resources in the Nunavut Settlement Area" (Priest and Usher 2004:11). The WHS was initiated in June of 1996 and the monthly collection of harvest data from Inuit hunters continued until May 2001. Hunters were classified as occasional, active, or intensive and were asked to report the species of animal harvested, the number harvested, and in some cases, the location, sex, and age class of the animal. Spatial data were collected wherever possible for some species to help show patterns of use and to enable identification by herd or water body.

Combined data from the two studies document over 65,000 harvest locations for 18 mammals over a 75 -year period, collected from over 6000 Inuit hunters from all 25 communities in Nunavut. Eighteen mammals were identified in the NPC UOM study. Eight of those mammals that were included in the NWMB WHS also have spatial data. Both studies recorded harvest locations on 1:250,000 scale maps at a resolution of $0.5-1.0 \mathrm{~km}$. The data for the eight mammals common to both datasets were combined to provide a rich and detailed picture of the geographic distribution for these mammals depicted by harvest patterns.

In this study we have adopted the term Inuit knowledge (IK) to describe the harvest data as ATK species occurrence and distribution information. We acknowledge that this basic information is presented in isolation from the rich and layered TEK that accompanied its documentation during the participant interviews. Observations of animals of a particular species by Inuit while hunting clearly do not constitute all of Inuit knowledge. They do, however, relate to the breadth and depth of Inuit knowledge of that species. To be successful hunters, Inuit will seek animals informed by the synthesis of their knowledge of appropriate habitat, seasonal behavior, and past experiences.

It is also important to acknowledge two data limitations. First, all harvest points are within Nunavut territorial boundaries 
and second, Inuit harvest sites are limited by geographic access, hunting time on the land, water access around coastline and ice edges, proximity to communities, and the impact of recent and significant socioeconomic shifts, thus actual mammal ranges could be larger than those depicted by harvesting patterns

This research provided an opportunity to apply the comprehensive harvest spatial data to the formal species at risk assessment process. The goal of this study was to derive geographic range values from the harvest data to apply to Phase I of the COSEWIC assessment process. These IK values, derived from harvest data, were then compared to existing COSEWIC values and designations. The results of the application and comparison were explored and the impacts of the results on status designations, discrepancies between values, the use of DUs, and insights on the challenges within the assessment process for the mammals used in this study were identified.

The authors were given explicit permission to use the Use and Occupancy data from the Nunavut Planning Commission's Use and Occupancy Mapping Study and although the Nunavut Wildlife Management Board's Wildlife Harvest Study data are publically available, permission was also requested and received. Both organizations were fully informed of research methods and objectives and have received full study results. Analysis was conducted using aggregated datasets, thus individual participants cannot be identified.

\section{METHODS}

The aggregated data for the eight mammals common to the UOM and WHS studies were combined into individual shapefiles and the point data for each were added to a preprepared map template for Nunavut. In all steps, ESRI ArcGIS (ArcEditor, version 9.3.1, SP1) software was used. The point distribution for these mammals was examined alongside distribution maps obtained from other (non-Inuit) sources. A final subset of five mammals, i.e., beluga whales (Delphinapterus leucas), narwhal whales (Monodon monoceros), polar bears (Ursus maritimus), Atlantic walrus (Odobenus rosmarus rosmarus), and Peary Caribou (Rangifer tarandus pearyi) was selected on the basis that the majority of the species distribution occurred within Nunavut and that there were extensive numbers of harvest points for that species. The five species selected have also been assessed to be at some degree of risk by COSEWIC thus establishing a basis for comparison.

To proceed with the application of the harvest data to the COSEWIC criteria, the five species were then divided into subpopulations or DUs as identified by COSEWIC. COSEWIC map images from status reports (COSEWIC $2004 a, b, c, 2006,2008)$ of the geographic boundaries of the DUs for these five species were georeferenced and then added as an overlay to each IK map. IK point assignments were made within the DUs and new point shapefiles were created. Not all of the DUs were fully represented within the borders of Nunavut by the IK data; therefore an estimate was made of the proportion of the DU occurring within the territory. The final study group is presented in Table 1. It should be noted that although the polar bear and walrus DUs are recognized by COSEWIC as distinct populations with unique risk factors, they are currently assessed on a species basis. There is, however, strong potential that these DUs will be used in the near future and therefore an analysis at the DU level is informative.

Extent of occurrence for the harvest data (IKEO) was calculated for each of the DUs according to available COSEWIC guidelines using the convex hull method (COSEWIC 2011a). This method calculates the area within a minimum convex polygon (no internal angle exceeds $180^{\circ}$ ) that includes all species localities. The convex hull points and polygons for nine of the DUs studied are illustrated in Figure 3.

Fig. 3. Inuit knowledge (IK) extent of occurrence (EO) convex hull polygons for nine designated units. See Appendix 1 for glossary of acronyms.

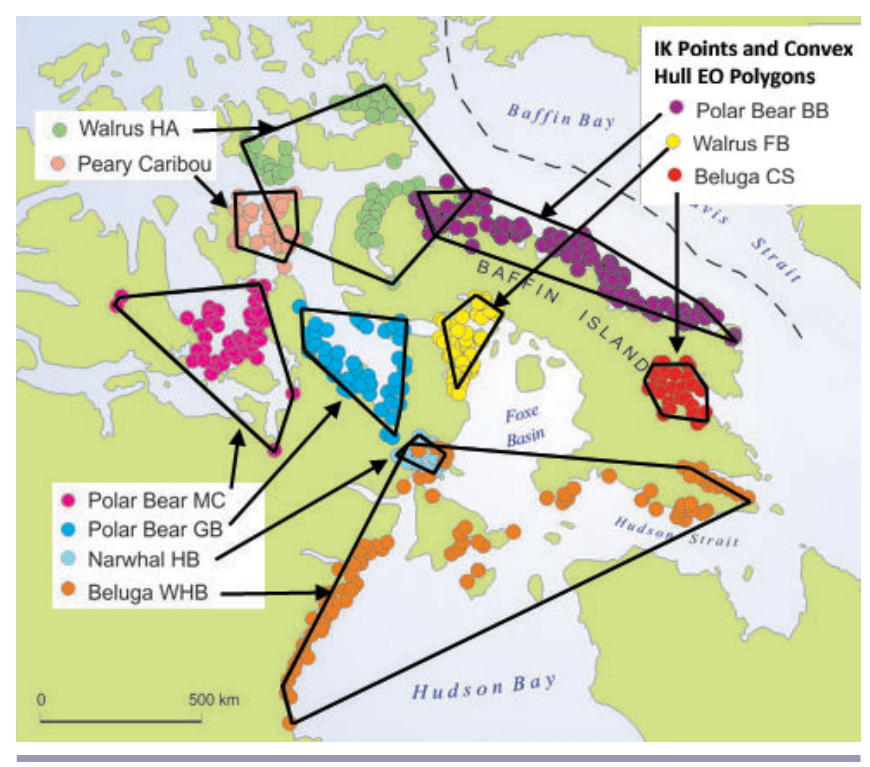

Area of occupancy for the harvest data (IKAO) was calculated for each of the DUs following the method outlined in the document Guidelines for the Use of the Index of Area of Occupancy (IAO) in COSEWIC Assessments (COSEWIC $2010 c$ ). This method applies a $2 \times 2 \mathrm{~km}$ grid to the potentially occupied areas and sums the number of cells actually occupied (Fig. 4). Only IAO values are used in the formal assessment procedure in Phase I, Section B. COSEWIC retains the use of the general term $\mathrm{AO}$ as a "biologically defensible estimate" of species occupation of habitat that can be used as a contextual 
Table 1. Study group: Inuit knowledge mammal species and subpopulations (Committee on the Status of Endangered Wildlife in Canada = COSEWIC; designatable units $=$ DUs).

\begin{tabular}{|c|c|c|c|c|}
\hline Species & Population (DU) & $\begin{array}{c}\text { Number of Harvest } \\
\text { Locations }\end{array}$ & $\begin{array}{c}\% \text { of COSEWIC Range } \\
\text { within Nunavut }\end{array}$ & $\begin{array}{l}\text { Population Corresponds to } \\
\text { COSEWIC DU? }\end{array}$ \\
\hline \multirow{3}{*}{$\begin{array}{l}\text { Beluga Whale } \\
\text { (Delphinapterus leucas) }\end{array}$} & Cumberland Sound & 228 & 100 & yes \\
\hline & East High Arctic & 480 & 100 & yes \\
\hline & Western Hudson Bay & 1577 & 33 & yes \\
\hline \multirow{2}{*}{$\begin{array}{l}\text { Narwhal } \\
\text { (Monodon monoceros) }\end{array}$} & Baffin Bay & 1449 & 75 & yes \\
\hline & Hudson Bay & 177 & 100 & yes \\
\hline \multirow{6}{*}{$\begin{array}{l}\text { Polar Bear } \\
\text { (Ursus maritimus) }\end{array}$} & Baffin Bay & 238 & 50 & $\mathrm{n} / \mathrm{a}$ \\
\hline & Foxe Basin & 490 & 80 & $\mathrm{n} / \mathrm{a}$ \\
\hline & Gulf of Boothia & 133 & 100 & $\mathrm{n} / \mathrm{a}$ \\
\hline & Lancaster Sound & 515 & 100 & $\mathrm{n} / \mathrm{a}$ \\
\hline & McClintock Channel & 81 & 50 & $\mathrm{n} / \mathrm{a}$ \\
\hline & Norwegian Bay & 32 & 80 & $\mathrm{n} / \mathrm{a}$ \\
\hline \multirow{3}{*}{$\begin{array}{l}\text { Walrus } \\
\text { (Odobenus rosmarus rosmarus) }\end{array}$} & Foxe Basin & 902 & 100 & yes \\
\hline & High Arctic & 231 & 75 & yes \\
\hline & Hudson Bay/Davis Str. & 646 & 90 & yes \\
\hline \multirow{2}{*}{$\begin{array}{l}\text { Peary Caribou } \\
\text { (Rangifer tarandus pearyi) }\end{array}$} & High Arctic & 384 & 90 & yes \\
\hline & Low Arctic & 111 & 100 & yes \\
\hline
\end{tabular}

consideration in species assessment (COSEWIC 2010c). AO values are sometimes reported within the text of status reports, but there are no details available on methods used by researchers to calculate this version of AO (COSEWIC $2010 c)$.

Fig. 4. Area of occupancy (AO) illustration using $2 \times 2 \mathrm{~km}$ grid cell applied to narwhal (Monodon monoceros) harvest points.

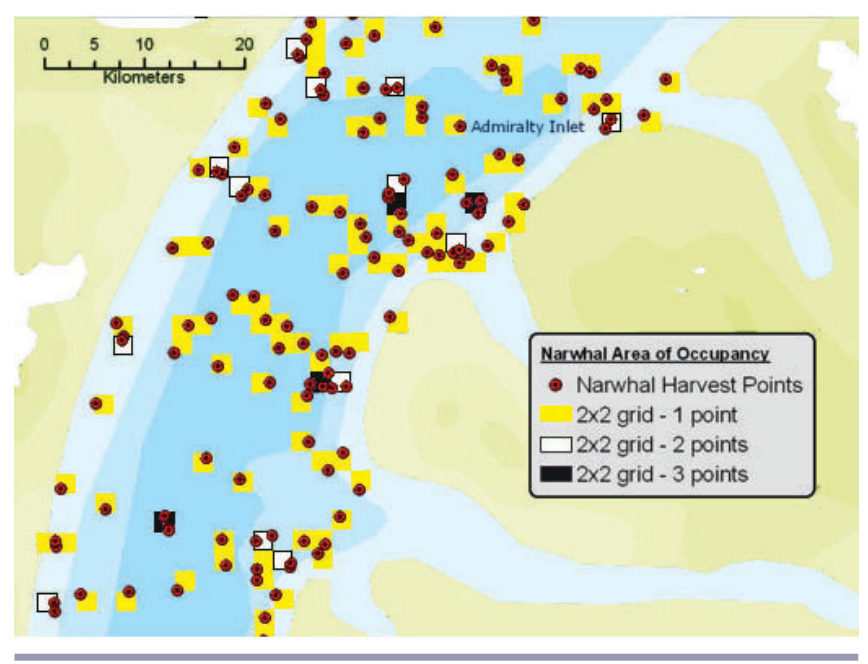

The IKEO and IKAO values were adjusted to represent $100 \%$ of the species range and were then applied to Section $B$ of the COSEWIC criteria. If the IK values were below the
COSEWIC threshold values for either parameter, then a potential risk status designation was assigned to the DU. The IK values and risk status designations were then compared with values available from COSEWIC status reports, from technical summaries, and from within the text.

\section{RESULTS}

The IKEO and IKAO range values were calculated and potential risk designations determined based on COSEWIC criteria thresholds in Section B of the assessment process (Fig. 2). The IK values and designations were compared with available COSEWIC data. Results are presented in Table 2.

Twelve IKAO values triggered a potential threatened $(\mathrm{TH})$ or endangered (EN) status. The IKEO values for narwhal Hudson Bay (HB) and polar bear Norwegian Bay (NW) triggered a potential threatened status. It is important to remember that these criteria are considered within the COSEWIC process in conjunction with fragmentation, decline, and fluctuations in $\mathrm{EO}, \mathrm{IAO}$, and numbers of locations or populations and number of mature individuals. EO and $\mathrm{AO}$ values are one component of this segment of the assessment; nonetheless they trigger potential risk status designations.

The results of the comparison of IK values with COSEWIC available data illustrate that there are few similarities between the IK range values and the COSEWIC range values. COSEWIC values were obtained from published COSEWIC status reports and include values from the technical summary and values extracted from within the descriptive text of status reports. Where COSEWIC AO values were available, they 
Table 2. Application of Inuit knowledge (IK) extent of occurrence (EO) and IK area of occupancy (AO) values to Committee on the Status of Endangered Wildlife in Canada (COSEWIC) criteria and comparison with COSEWIC values. See Appendix 1 for glossary of acronyms.

\begin{tabular}{|c|c|c|c|c|c|c|}
\hline DU/Population & $\begin{array}{c}\mathrm{IK} \\
\text { Extent of } \\
\text { Occurrence } \\
\mathrm{km}^{2}\end{array}$ & $\begin{array}{l}\text { COSEWIC EO } \\
\mathrm{km}^{2}\end{array}$ & $\begin{array}{c}\mathrm{IK} \\
\text { Area of } \\
\text { Occupancy } \\
\mathrm{Km}^{2}\end{array}$ & $\begin{array}{l}\text { COSEWIC } \\
\text { Index of } \\
\mathrm{AO} \mathrm{km}{ }^{2}\end{array}$ & $\begin{array}{l}\text { COSEWIC Status } \\
\text { Designation }\end{array}$ & $\begin{array}{l}\text { IK Status } \\
\text { Designation }\end{array}$ \\
\hline \multicolumn{7}{|l|}{$\begin{array}{l}\text { BELUGA } \\
\text { (Delphinapterus leucas) }\end{array}$} \\
\hline Cumberland Sound & 23,409 & 27,000 & 592 & 9000 & Threatened & Threatened \\
\hline Eastern High Arctic & 626,687 & 250,000 & 1068 & 49,000 & Special Concern & Threatened \\
\hline $\begin{array}{l}\text { West. Hudson Bay } \\
\text { NARWHAL } \\
\text { (Monodon monoceros) }\end{array}$ & $1,763,636$ & 770,000 & 7139 & 51,000 & Special Concern & Not at Risk \\
\hline Baffin Bay & $1,052,492$ & $1,250,000$ & 3690 & 60,000 & Special Concern & Not at Risk \\
\hline $\begin{array}{l}\text { Hudson Bay } \\
\text { POLAR BEAR } \\
\text { (Ursus maritimus) }\end{array}$ & 8750 & 60,000 & 292 & 17,000 & Not at Risk & Endangered \\
\hline Polar Bear BB & 304,012 & & 868 & & & Threatened \\
\hline Polar Bear FB & 815,790 & & 2135 & & & Not at Risk \\
\hline Polar Bear GB & 78,590 & & 496 & & & Endangered \\
\hline Polar Bear LS & 266,251 & & 1864 & & & Threatened \\
\hline Polar Bear MC & 146,469 & & 304 & & & Endangered \\
\hline Polar Bear NW & 14,454 & & 116 & & & Endangered \\
\hline IK Total population & $3,400,092$ & & & & & Not at Risk \\
\hline $\begin{array}{l}\text { Canadian population } \\
\text { WALRUS } \\
\text { (Odobenus rosmarus rosmarus) }\end{array}$ & & $8,700,000$ & & $5,600,000$ & Special Concern & \\
\hline Foxe Basin & 31,219 & 50,000 & 1460 & $\mathrm{n} / \mathrm{a}$ & & Threatened \\
\hline High Arctic & 354,305 & 150,000 & 1018 & $\mathrm{n} / \mathrm{a}$ & & Threatened \\
\hline $\mathrm{HB} / \mathrm{DS}$ & 958,554 & 385,000 & 2031 & $\mathrm{n} / \mathrm{a}$ & & Not at Risk \\
\hline IK Total pop. ${ }^{\dagger}$ (No B.I.) & $1,702,865$ & & & & & Not at Risk \\
\hline $\begin{array}{l}\text { Canadian Population } \\
\text { PEARY CARIBOU } \\
\text { (Rangifer tarandus pearyi) }\end{array}$ & & 750,000 & & & Special Concern & \\
\hline $\begin{array}{l}\text { Peary High Arctic (Queen Eliz } \\
\text { Islands) }\end{array}$ & 163,866 & 419,061 & 1249 & $\mathrm{n} / \mathrm{a}$ & Endangered & Threatened \\
\hline $\begin{array}{l}\text { Peary Low Arctic (PW/ } \\
\text { Somerset Is.) }\end{array}$ & 37,977 & 59,065 & 616 & $\mathrm{n} / \mathrm{a}$ & Endangered & Threatened \\
\hline
\end{tabular}

Bold $=$ values below COSEWIC thresholds and potential risk status triggered.

${ }^{\dagger}$ Belcher Island harvest points not included.

were considerably different from and usually substantially higher than the AO values derived from the IK data. IKEO values had some degree of congruency with COSEWIC EO's (beluga Cumberland Sound [CS], narwhal Baffin Bay [BB], walrus Foxe Basin [FB], and Peary caribou Low Arctic [LA]).

The comparison of status designations for beluga and narwhal whales and Peary caribou is summarized in Table 3. This comparison does not include polar bear and walrus. Only one population shared the same status designation (threatenedbeluga CS). This illustrates a substantial difference between the two sets of data and particularly emphasizes the designation of special concern by COSEWIC in cases where IK data indicate the population may be at risk. The assignment of special concern is the result of a subjective decision making process within COSEWIC and it was not appropriate to assign this status to the IK data. A species may be up listed to special concern if the species criterion values are near to qualifying, if a decline is not quite sufficient to qualify, if identified threats are not being effectively reversed or managed, or if a species is uniquely susceptible to a catastrophic event (COSEWIC 2010a). A species may be down listed to special concern when a rescue effect is clearly identified. Rescue effect refers to the potential of extraregional populations to mitigate the decline of another population by migration and subsequent effective reproduction (COSEWIC 2010a).

Comparison between the IK and COSEWIC values for polar bears was difficult. There are currently 13 identified subpopulations or DUs within Canada and a world total of 19 (COSEWIC 2008). Risk assessment is conducted on a species basis for polar bears in Canada but the bears are managed at the DU level. IKEO and AO values were calculated for six 
Table 3. Inuit Knowledge (IK) and Committee on the Status of Endangered Wildlife in Canada (COSEWIC) status designation comparison summary. See Appendix 1 for glossary of acronyms.

\begin{tabular}{lccccc}
\hline \hline & & \multicolumn{3}{c}{ COSEWIC Status Designations } \\
\cline { 2 - 5 } IK Status Designation & EN & TH & SC & NAR & TOTAL \\
\hline EN & 0 & 0 & 0 & 1 & 1 \\
TH & 2 & 1 & 1 & 0 & 4 \\
SC & 0 & 0 & 0 & 0 & 0 \\
NAR & 0 & 0 & 2 & 3 & 7 \\
TOTAL & 2 & 1 & 3 & & 1 \\
\hline
\end{tabular}

polar bear management DUs within Nunavut, and the IKEO for the total number within Nunavut, whereas the COSEWIC $\mathrm{EO}$ and $\mathrm{AO}$ values reflect the entire Canadian population, therefore there is no compatible geographic basis for comparison. Figure 5 illustrates the IKEO polygon for the polar bear population in Nunavut along with COSEWIC EO and AO polygons (reproduced from COSEWIC 2008). The COSEWIC polygons do not appear to be drawn according to COSEWIC guidelines. The COSEWIC EO (red outline) is not a convex hull polygon and the AO (yellow outline) includes areas of obvious unsuitable habitat.

Fig. 5. Comparison of Inuit knowledge (IK) extent of occurrence (EO) for polar bear (Ursus maritimus) designatable units with IK Nunavut EO and Committee on the Status of Endangered Wildlife in Canada (COSEWIC) EO and area of occupancy (AO; COSEWIC 2008). See Appendix 1 for glossary of acronyms.

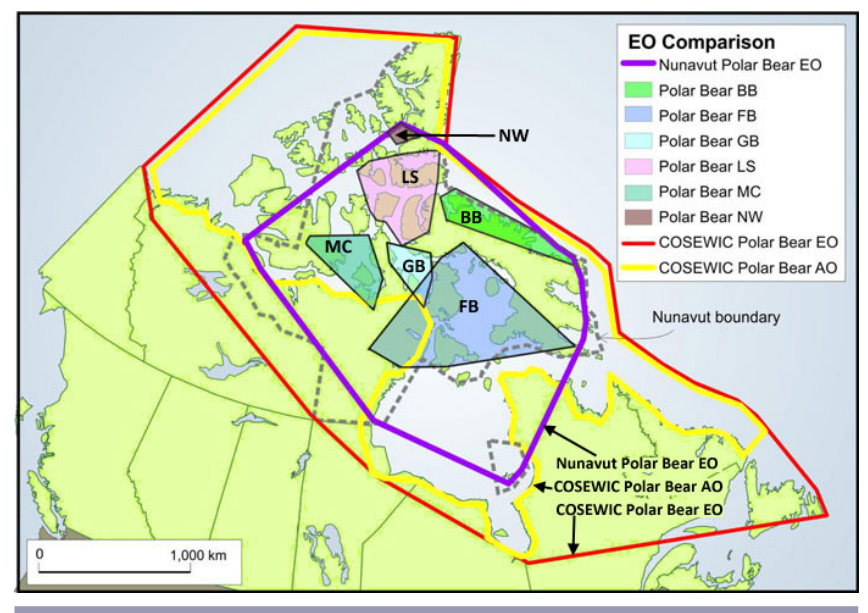

Figure 5 does illustrate that if risk assessment was conducted on a DU basis for polar bears, then the EO and AO values would be much smaller resulting in five subpopulations at risk. Because COSEWIC assesses the polar bear by species, no quantitative values in Phase I fell below threshold values, however, the status designation of special concern has been applied nonetheless. The debate around the use of DUs in polar bear risk assessment is reflected in the literature with some (Thiemann et al. 2008) arguing for the use of five polar bear DUs in Canada, whereas others (Paetkau et al. 1999) found four Canadian population clusters based on genetic distances. Thiemann et al.'s more recent conclusions were based on intrinsic data such as genetics, but also on extrinsic data such as ice conditions and prey abundance. They concluded that the five polar bear groups were separate units of biodiversity with regionally specific conservation needs; however, they supported the continued use of the 13 Canadian DUs for sustainable harvest management purposes.

COSEWIC recognizes subpopulations (or DUs) within the walrus population in Canada for management purposes, but along with the polar bear, risk is assessed at the species level. If assessed at the DU level, IKAO values for two walrus DUs would trigger a potential threatened status while IKEO values were above COSEWIC threshold values. The IKEO polygon for the walrus Foxe Basin subpopulation appears to be quite small (Fig. 6). However, the value of $31,219 \mathrm{~km}^{2}$ is above the COSEWIC threshold value of $20,000 \mathrm{~km}^{2}$. COSEWIC has designated the walrus as special concern at the species level primarily because of the vulnerability of the species through over-hunting while acknowledging that information on population sizes and structure is insufficient to assess on a DU basis, even if warranted (COSEWIC 2006).

\section{DISCUSSION}

The goal of this study was to explore the inclusion of ATK (IK) in the form of harvest data in risk assessment with the geospatial data from two comprehensive Nunavut datasets using COSEWIC-established evaluation criteria. A subset of five mammals was selected to study on the basis that each had sufficient spatial data in number and extent within Nunavut and these species had been assessed by COSEWIC to be at some degree of risk.

The IKAO values calculated were very low. When applied to Phase I of the assessment process many IKAO values fell below COSEWIC threshold levels, triggering a potential threatened status for 12 of the 15 subpopulations (DUs). This suggests at least two possible interpretations. First, the results are correct and these mammal DUs are potentially at risk. 
Second, these results could also indicate that there may be additional ecological or biological elements, such as a species' home range, that need to factor into the calculation of $\mathrm{AO}$ reflecting issues with COSEWIC's guidelines for calculations, or a lack of transparency within the calculation methodology. It is notable that researchers are directed to contact the COSEWIC Secretariat for input around the calculation of EO, AO, and IAO (COSEWIC 2011a).

Fig. 6. Inuit knowledge extent of occurrence (IKEO) polygons for walrus (Odobenus rosmarus rosmarus) designatable units (DUs). See Appendix 1 for glossary of acronyms.

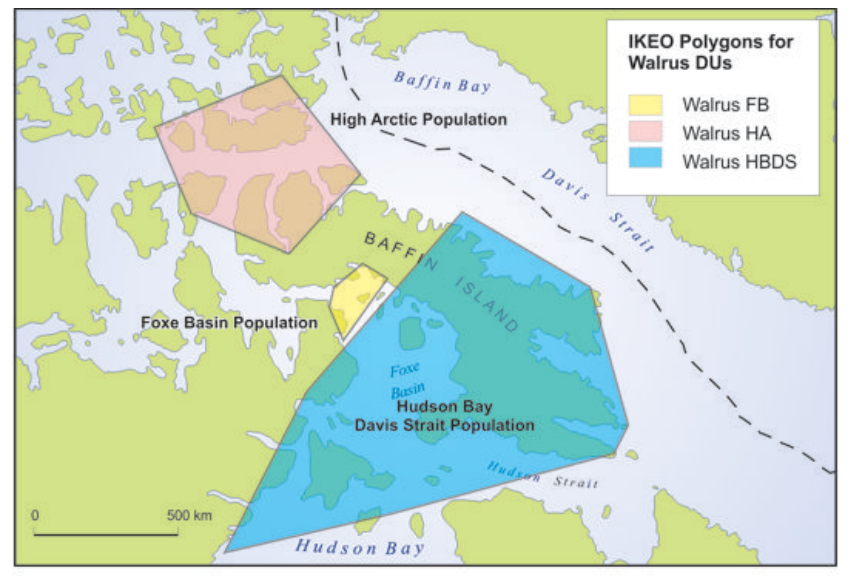

When the IKEO and IKAO values were compared to the available COSEWIC values, there was little congruency. The $\mathrm{AO}$ values were not similar. IK and COSEWIC EO values were somewhat similar in a few cases however status designations only lined up in one case. These results are provocative and some reasons for the disparity in results were examined.

It is notable that only geospatial point data were used for the calculations of IKEO and IKAO. Although rich in number and extent, the IK data are representative of harvest sites within Nunavut only and limited by reflecting only those areas accessed by participants in both studies. Geographic features also limit hunter access to areas that a species may occupy. Actual species ranges presumably extend beyond hunting areas. These facts can be identified as contributors to the smaller AO values obtained in this research.

Other factors potentially impacting on the disparity in results stem from the method used to calculate AO. Issues with calculation scale and the incorporation of biologically relevant considerations were examined.

COSEWIC directs researchers to use a $2 \times 2 \mathrm{~km}$ grid superimposed on point occurrence data, when available, for the calculation of AO. The extensive point data within the IK data sets allowed for this direct application. However, when extensive point occurrence data are not available at the $2 \times 2$ $\mathrm{km}$ scale, occurrence is estimated by other methods that consider combinations of variables such as sampling intensity, core habitat availability, core diet availability, and other life history trait categories (Jetz et al. 2007, Van der Veken et al. 2007). The grid size used varies substantially depending on species and size of sampling effort (collection resolution) and can range from a few meters to hundreds of kilometers (Collingham et al. 2000, Riba et al. 2002). Researchers working with incomplete datasets (sampled site fractions within EO) have utilized the grid-based method as an initial step to determine a proportion of occupancy in their available sampled grids and then extrapolated that value into other areas that have similar habitat characteristics (Goehring et al. 2007). These alternate methods consistently include errors of commission and result in inflated $\mathrm{AO}$ values (Gaston and Fuller 2009). This fact could contribute to why IKAO values appear small.

Using a $2 \times 2 \mathrm{~km}$ grid also excludes key biologically relevant information. A $2 \times 2 \mathrm{~km}$ grid does not reflect a normal range of movement for many species and thus cannot be a representative base unit upon which to calculate actual area of occupancy for all species. Species specific movement distances should be a critical consideration when calculating the actual amount of habitat utilized by a species for breeding, feeding, and other essential biophysical processes, i.e., the definition of AO. For example, beluga whales may move around in an area of up to $30 \mathrm{~km}^{2} /$ day in the summer as they remain near plentiful feeding grounds (Hobbs et al. 2005), whereas muskoxen (Ovibos moschatus) may only have a movement range of no more than $12 \mathrm{~km}^{2} /$ day while in their winter territory (Reynolds 1991). Adding this value around each IK point, excluding obviously unsuitable habitat, would result in a combined area more biologically representative of that population. This inclusion would substantially increase IKAO values.

This concept would be easiest to apply for nonmigratory species such as polar bears, wolverines (Gulo gulo), grizzly bears (Ursus arctos horribilis), wolves (Canis lupus), or species such as muskoxen that undertake shorter seasonal migratory shifts. It would be more difficult to apply for migratory species such as belugas, narwhals, walrus, and caribou. These mammals have established summering and wintering areas that are assessed independently from the migratory route areas and this concept could be applied for those seasonal territories. If this adjustment was factored into the IKAO calculations, the IKAO values would be much larger and less likely to fall below COSEWIC threshold values and be potentially at risk.

However, even if an $\mathrm{AO}$ was calculated according to a biologically relevant scale, there is still the issue of a fixed set 
of thresholds in the COSEWIC criteria. The EO threshold values of $<5000 \mathrm{~km}^{2}$ for endangered and $<20,000 \mathrm{~km}^{2}$ for threatened and the AO threshold values of $<500 \mathrm{~km}^{2}$ for endangered and $<2000 \mathrm{~km}^{2}$ for threatened are applied to all species and populations. It has been suggested that a set of different threshold levels should be established for groups of organisms that have similar biological and behavioral characteristics (Keith et al. 2000). The IK maps of EO polygons illustrate the enormous range of occurrence areas for the study group of arctic mammals, from very small, e.g., polar bear NB (Fig. 5) to very large, e.g., beluga WHB (Fig. 3) despite the fact that they are all large mammals. It is difficult to imagine that one set of threshold values could be a valid trigger for all of these species of the same class let alone species from other phylums.

The IUCN has debated the issue of fixed thresholds at the international level for the last decade and it has been pointed out that not all criteria in the assessment process are intended to be appropriate for all cases (Mace 1999). Phase I Section $\mathrm{B}$ of the COSEWIC process that focuses on range values is apparently intended to identify those species that are at risk because of the small areas they occupy as opposed to issues of population size or an ongoing decline. This suggests that area criterion is only effective for species that are small in size, sessile species, or those species that have a very small home range of movement. It follows that these criteria are not going to be appropriate indicators of risk for mammals such as beluga and narwhal whales, walrus, polar bear, and caribou.

In section 4.10.6 of the guidelines for calculating $\mathrm{AO}$ (COSEWIC 2010c) COSEWIC also expresses a concern regarding species occupying linear habitats such as in rivers or along coastlines. In these cases the application of a grid would not have the same ecological meaning as for more uniformly dispersed species. They suggest that a 1x1 km grid size might be more appropriate for animals with coastal habitats, but still direct the use of a $2 \times 2 \mathrm{~km}$ grid cell in all cases. Using a $1 \times 1 \mathrm{~km}$ grid with the mammals in this research, many of which occupy coastal habitats, predictably resulted in much lower AO values. Addressing this concern within the context of this research only exacerbated the issue of low IKAO values.

Within the mammal group studied, COSEWIC assigned a special concern status to two species, polar bear and walrus, and three DUs, beluga EHA and WHB, and narwhal BB. Special concern essentially indicates that risk is possible, imminent, or likely, although the assessment criteria do not qualify for a status designation of threatened or endangered (COSEWIC 2010a). Currently, the special concern designation does not qualify for any level of conservation program implementation through SARA, but it does increase the profile of the species in question. The prevalence of special concern designations in arctic mammals could also reflect a lack of solid data. Arctic animals are difficult and expensive to study. The Inuit harvest data are an extremely valuable addition to the knowledge base for these animals.

\section{CONCLUSION}

The Inuit harvest data from the two studies in Nunavut are rich and valuable sources of information on the geographic distribution of arctic mammals. The point occurrence data and quantitative range values of $\mathrm{EO}$ and $\mathrm{AO}$ can be included in wildlife management in general and in the COSEWIC assessment process specifically as ATK. When a status report is prepared for COSEWIC, the researcher is charged with collecting the best available information from all possible sources. Incorporating quantitative Inuit harvest spatial data is a tangible and substantial addition to the knowledge base and fulfills the mandate to include ATK in the risk assessment process.

This research suggests that COSEWIC needs to establish standard methodologies in its protocol when calculating the range values of $\mathrm{EO}$ and $\mathrm{AO}$. When the quantitative criteria used in Phase I are being calculated, the process should be transparent and repeatable. Current instructions for researchers preparing status reports include a mandatory consultation with the COSEWIC Secretariat to determine the range values of EO, AO, and IAO. The difficulty for those not researching for status reports and not in contact with the Secretariat is that there is not enough accessible information available to be absolutely clear about how these calculations should be made.

For the assessment process to realistically reflect the risk status of the species, COSEWIC needs to use stricter definitions of $\mathrm{EO}$ and $\mathrm{AO}$, and clarify their use within the process. COSEWIC's use of the Index of Area of Occupancy (IAO) as well as a "biological" AO, contributes to confusion about the calculation of values, the meaning of values, and their application. The derivation of the biological AO has not been made clear by COSEWIC and the imprecise language used describing the calculation options (see COSEWIC 2010c) essentially leaves the methodology up to the researcher.

Ideally, biologically appropriate and species specific threshold levels should be developed to allow for legitimate applications of range values. Application context and research objectives need to be carefully considered when attempting to standardize a method to calculate $\mathrm{AO}$. Calculating an $\mathrm{AO}$ value from point occurrence data without considering any other biological variables, as is the case with this research, may have limited or minimal utility if comparisons are attempted with results obtained using different or undisclosed methods. In conservation, for $\mathrm{AO}$ to be meaningful, the accuracy used and methods employed should reflect the biology of the species. Until more research is done, the use of AO, especially in risk assessment, is questionable. 
Inuit knowledge of mammal distribution in Nunavut is extensive, historically rich, and ongoing. It represents a unique and substantial opportunity to enrich the knowledge base for arctic mammals and to be used in wildlife management and conservation planning. The clearly quantitative nature of these data sets minimizes the potential of information misappropriation. This research has illustrated that harvest location spatial data from Nunavut can be used to derive quantitative geographic range values that can be applied to the risk assessment criterion in COSEWIC. This application also provided insight into the challenges within the COSEWIC assessment process that need to be addressed. Future research with existing data from Nunavut studies could contribute to essential wildlife management processes and work toward solidifying the critical Canadian conservation effort.

Responses to this article can be read online at: http://www.ecologyandsociety.org/voll7/iss3/art4/responses/

\section{Acknowledgments:}

The authors thank the Nunavut Planning Commission for providing access to the UOM data and for the assistance provided by Mike Townsend. The Nunavut Wildlife Management Board was supportive of our use of the data from the Wildlife Harvest Study. Dr. Tom Nudds of Integrative Biology, University of Guelph, assisted in the development of the research framework. Financial assistance for travel to Nunavut was provided by the Northern Scientific Training Program.

\section{LITERATURE CITED}

Agrawal, A. 1995. Dismantling the divide between indigenous and scientific knowledge. Development and Change 26:413-439.

Armitage, D. R. 2005. Community-based narwhal management in Nunavut, Canada: change, uncertainty, and adaptation. Society \& Natural Resources 18:715-731. http://d x.doi.org/10.1080/08941920591005124

Bala, A., and G. G. Joseph. 2007. Indigenous knowledge and western science: the possibility of dialogue. Race \& Class 49 (1):39-61. http://dx.doi.org/10.1177/0306396807080067

Berkes, F., M. K. Berkes, and H. Fast. 2007. Collaborative integrated management in Canada's north: the role of local and traditional knowledge and community-based monitoring. Coastal Management 35:143-162. http://dx.doi.org/10.1080/0 $\underline{8920750600970487}$

Berkes, F., J. Colding, and C. Folke. 2000. Rediscovery of traditional ecological knowledge as adaptive management. Ecological Applications 10(5):1251-1262. http://dx.doi.org/1 0.1890/1051-0761(2000)010[1251:ROTEKA]2.0.CO;2
Boitani, L., I. Sinibaldi, F. Corsi, A. De Biase, I. d'Inzillo Carranza, M. Ravagli, G. Reggiani, C. Rondinini, and P. Trapenese. 2008. Distribution of medium- to large-sized African mammals based on habitat suitability models. Biodiversity and Conservation 17:605-621. http://dx.doi.org/ $\underline{10.1007 / \mathrm{s} 10531-007-9285-0}$

Brook, R. K., and S. M. McLachlan. 2005. On using expertbased science to "test" local ecological knowledge. Ecology and Society 10(2): r3. [online] URL:http://www.ecologyands ociety.org/vol10/iss2/resp3/

Collingham, Y. C., R. A. Wadsworth, B. Huntley, and P. E. Hulme. 2000. Predicting the spatial distribution of nonindigenous riparian weeds: issues of spatial scale and extent. Journal of Applied Ecology 37:13-27. http://dx.doi.org/10.1046/ j.1365-2664.2000.00556.x

Committee on the Status of Endangered Wildlife in Canada (COSEWIC). 2002. COSEWIC assessment and update status report on the woodland caribou Rangifer tarandus caribou in Canada. COSEWIC, Ottawa, Ontario, Canada. [online] URL: http://www.sararegistry.gc.ca/virtual_sara/files/cosewic/ $\underline{\text { sr woodland caribou e.pdf }}$

Committee on the Status of Endangered Wildlife in Canada (COSEWIC). 2004a. COSEWIC assessment and update status report on the beluga whale Delphinapterus leucas in Canada. COSEWIC, Ottawa, Ontario, Canada. [online] URL: http://w ww.sararegistry.gc.ca/virtual sara/files/cosewic/sr beluga whale e. pdf

Committee on the Status of Endangered Wildlife in Canada (COSEWIC). 2004b. COSEWIC assessment and update status report on the narwhal Monodon monoceros in Canada. COSEWIC, Ottawa, Ontario, Canada. [online] URL: http://w ww.sararegistry.gc.ca/virtual sara/files/cosewic/sr narwhal e. pdf

Committee on the Status of Endangered Wildlife in Canada (COSEWIC). 2004c. COSEWICAssessment and update status report on the Peary caribou Rangifer tarandus pearyi and the barren-ground caribou Rangifer tarandus groenlandicus Dolphin and Union population in Canada. COSEWIC, Ottawa, Ontario, Canada. [online] URL: http://www.sararegi stry.gc.ca/virtual_sara/files/cosewic/sr_peary_caribou_e.pdf

Committee on the Status of Endangered Wildlife in Canada (COSEWIC). 2006. COSEWIC assessment and update status report on the Atlantic walrus Odobenus rosmarus rosmarus in Canada. COSEWIC, Ottawa, Ontario, Canada. [online] URL: http://www.sararegistry.gc.ca/virtual sara/files/cosewic/ $\underline{\text { sr atlantic walrus e.pdf }}$

Committee on the Status of Endangered Wildlife in Canada (COSEWIC). 2008. COSEWIC assessment and update status report on the polar bear Ursus maritimus in Canada. 
COSEWIC, Ottawa, Ontario, Canada. [online] URL: http://w ww.sararegistry.gc.ca/virtual sara/files/cosewic/ $\underline{\text { sr polar bear } 0808 \text { e.pdf }}$

Committee on the Status of Endangered Wildlife in Canada (COSEWIC). 2010a. COSEWIC's assessment process and criteria. (Approved April 2010). COSEWIC, Ottawa, Ontario, Canada. [online] URL: http://www.cosewic.gc.ca/pdf/assessm ent process e.pdf

Committee on the Status of Endangered Wildlife in Canada (COSEWIC). 2010b. COSEWIC Aboriginal traditional knowledge (ATK) process and protocols guidelines. (updated December 2010). [online] URL: http://www.cosewic.gc.ca/eng/ sct0/ppg e.cfm

Committee on the Status of Endangered Wildlife in Canada (COSEWIC). 2010c. Guidelines for use of the index of area of occupancy (IAO) in COSEWIC assessments. (Approved April 2009). [online] URL: http://www.cosewic.gc.ca/eng/sct2/ sct2_7_e.cfm

Committee on the Status of Endangered Wildlife in Canada (COSEWIC). 2011b. Guidelines for recognizing designatable units. (Approved November 2011). COSEWIC, Ottawa, Ontario, Canada. [online] URL: http://www.cosewic.gc.ca/eng/ sct2/sct2_5_e.cfm

Committee on the Status of Endangered Wildlife in Canada (COSEWIC). 2011a. Instructions for the preparation of COSEWIC status reports. (Updated November 2011). COSEWIC, Ottawa, Ontario, Canada. [online] URL: http://w ww.cosewic.gc.ca/pdf/Instructions_e.pdf

Dowsley, M. 2009. Community clusters in wildlife and environmental management: using TEK and community involvement to improve co-management in an era of rapid environmental change. Polar Research 28:43-59. http://dx.do i.org/10.1111/j.1751-8369.2008.00093.x

Duerden, F., and R. G. Kuhn. 1998. Scale, context, and application of traditional knowledge of the Canadian north. Polar Record 34(188):31-38. http://dx.doi.org/10.1017/S0032 247400014959

Ellis, S. C. 2005. Meaningful consideration? A review of traditional knowledge in environmental decision making. Arctic 58(1):66-77.

Gaston, K. J. 1994. Measuring geographic range sizes. Ecography 17:198-205. http://dx.doi.org/10.1111/j.1600-058 7.1994.tb00094.x

Gaston, K. J., and R. A. Fuller. 2009. The sizes of species' geographic ranges. Journal of Applied Ecology 46:1-9. http:/ /dx.doi.org/10.1111/j.1365-2664.2008.01596.x

Gilchrist, G., and M. L. Mallory. 2007. Comparing expertbased science with local ecological knowledge: what are we afraid of? Ecology and Society 12(1): r1. [online] URL:http: //www.ecologyandsociety.org/vol12/iss1/resp1/

Gilchrist, G., M. Mallory, and F. Merkel. 2005. Can local ecological knowledge contribute to wildlife management? Case studies of migratory birds. Ecology and Society 10(1): 20. [online] URL: http://www.ecologyandsociety.org/vol10/iss1/ art20/

Goehring, D. M., G. C. Daily, S. Dasgupta, and P. R. Ehrlich. 2007. Range occupancy and endangerment: a test with a butterfly community. American Midland Naturalist 157:106-120. http://dx.doi.org/10.1674/0003-0031(2007)157 [106:ROAEAT]2.0.CO;2

Government of Canada. 1993. Nunavut Land Claims Agreement Act (S.C. 1993, c. 29). Department of Justice, Government of Canada, Ottawa, Ontario, Canada.

Government of Canada. 2002. Species at Risk Act (S.C. 2002, c. 29). Department of Justice, Government of Canada, Ottawa, Ontario, Canada.

Hobbs, R. C., K. L. Laidre, D. J. Vos, B. A. Mahoney, and M. Eagleton. 2005. Movements and area use of belugas Delphinapterus leucas, in a subarctic Alaskan estuary. Arctic 58(4)331-340.

Houde, N. 2007. The six faces of traditional ecological knowledge: challenges and opportunities for Canadian comanagement arrangements. Ecology and Society 12(2): 34. [online] URL: http://www.ecologyandsociety.org/vol12/iss2/ art34/

Hurlbert, A. H., and W. Jetz. 2007. Species richness, hotspots, and the scale dependence of range maps in ecology and conservation. Proceedings of the National Academy of Sciences of the United States of America 104:13384-13389. http://dx.doi.org/10.1073/pnas.0704469104

International Union for Conservation of Nature and Natural Resources (IUCN). 2001. IUCN red list categories and criteria: Version 3.1. IUCN Species Survival Commission. IUCN, Gland, Switzerland and Cambridge, UK.

Jetz, W., C. H. Sekercioglu, and J. E. M. Watson. 2007. Ecological correlates and conservation implications of overestimating species geographic ranges. Conservation Biology 22:110-119. http://dx.doi.org/10.1111/j.1523-1739.2 007.00847.x

Keith, D. A., T. D. Auld, M. K. J. Ooi, and B. D. E. Mackenzie. 2000. Sensitivity analyses of decision rules in World Conservation Union (IUCN) Red List criteria using Australian plants. Biological Conservation 94:311-319. http://dx.doi.org /10.1016/S0006-3207(99)00194-9

Kruse, J., D. Klein, S. Braund, L. Moorehead, and B. Simeone. 1998. Co-management of natural resources: a comparison of 
two caribou management systems. Human Organization 57 (4):447-458.

Kuhn, R. G., and F. Duerden. 1996. A review of traditional environmental knowledge: an interdisciplinary Canadian perspective. Culture XVI(1):71-84.

Lukey, J. R., and S. S. Crawford. 2009. Consistency of COSEWIC species at risk designations: freshwater fishes as a case study. Canadian Journal of Fisheries and Aquatic Sciences 66(6):959-971. http://dx.doi.org/10.1139/F09-054

Mace G. M. 1999. IUCN criterion review: report of the range areas and uncertainty workshop. IUCN, Gland, Switzerland and Cambridge, UK. [online] URL: http://intranet.iucn.org/w ebfiles/doc/SSC/RedList/Criteria Review Range Areas Un certainty_Workshop.pdf

Manseau, M., B. Parlee, and G. B. Ayles. 2005. A place for traditional ecological knowledge in resource management. Pages 141-164 in F. Berkes, R. Huebert, H. Fast, M. Manseau, and A. Diduck, editors. Breaking ice: renewable resource and ocean management in the Canadian north. University of Calgary Press and Arctic Institute of North America, Calgary, Alberta, Canada.

Moller, H., F. Berkes, P. O. Lyver, and M. Kislalioglu. 2004. Combining science and traditional ecological knowledge: monitoring populations for co-management. Ecology and Society 9(3): 2. [online] URL: http://www.ecologyandsociety. org/vol9/iss $3 /$ art2

Nadasdy, P. 1999. The politics of TEK: power and the "integration" of knowledge. Arctic Anthropology 36 (1/2):1-18.

Nadasdy, P. 2005. The anti-politics of TEK: the institutionalization of co-management discourse and practice. Anthropologica 47(2):215-232.

Natcher, D. C., S. Davis, and C. G. Hickey. 2005. Comanagement: managing relationships, not resources. Human Organization 64(3):240-250.

Paetkau, D., S. C. Amstrup, E. W. Born, W. Calvert, A. E. Derocher, G. W. Garner, F. Messier, I. Stirling, M. K. Taylor, $\varnothing$. Wiig, and C. Strobeck. 1999. Genetic structure of the world's polar bear populations. Molecular Ecology (8):1571-1584. http://dx.doi.org/10.1046/j.1365-294x.1999.00733. $\underline{\mathrm{x}}$

Omura, K. 2005. Science against modern sciencee: the sociopolitical construction of otherness in Inuit TEK (Traditional Ecological Knowledge). Senri Ethnological Studies (67):323-344.
Priest, H., and P. Usher. 2004. Nunavut wildlife harvest study. Nunavut Wildlife Management Board, Iqaluit, Nunavut, Canada.

Reynolds, P. E. 1991. Seasonal differences in the distribution and movements of muskoxen (Ovibos moschatus) in northeastern Alaska. Rangifer 12(3):171-172.

Riba, M., A. Rodrigo, B. Colas, and J. Retana. 2002. Fire and species range in Mediterranean landscapes: an experimental comparison of seed and seedling performance among Centaurea taxa. Journal of Biogeography 29:135-146. http:// dx.doi.org/10.1046/j.1365-2699.2002.00652.x

Simpson, L. 2001a. Aboriginal peoples and knowledge: decolonizing our processes. Canadian Journal of Native Studies XXI,1(2001):137-148.

Simpson, L. 2001b. Traditional ecological knowledge: marginalization, appropriation and continued disillusion. Indigenous Knowledge Conference, University of Saskatchewan, May 28-30. Saskatoon, Saskatchewan, Canada. [online] URL: http://datalib.usask.ca/iportal/2007.10.17/IKC-2001/IKC-papers. pdf\#page $=135$

Simpson, L. R. 2004. Anticolonial strategies for the recovery and maintenance of indigenous knowledge. American Indian Quarterly 28(3\&4):373-384. http://dx.doi.org/10.1353/aiq.20 $\underline{04.0107}$

Thiemann, G. W., A. E. Derocher, and I. Stirling. 2008. Polar bear Ursus maritimus conservation in Canada: an ecological basis for identifying designatable units. Oryx 42(4):514-515. http://dx.doi.org/10.1017/S0030605308001877

Tobias, T. N. 2009. Living proof: the essential data-collection guide for indigenous use-and-occupancy map surveys. Ecotrust Canada and Union of B.C. Indian Chiefs, Vancouver, British Columbia, Canada.

Usher, P. J. 2000. Traditional ecological knowledge in environmental assessment management. Arctic 53(2):183-193.

Van der Veken, S., J. Bellemare, K. Verheyen, and M. Hermy. 2007. Life history traits are correlated with geographical distribution patterns of western European forest herb species. Journal of Biogeography 34:1723-1735. http://dx.doi.org/10. 1111/j.1365-2699.2007.01738.x

Wenzel, G. W. 1999. Traditional ecological knowledge and Inuit: reflections on TEK and ethics. Arctic 52(2):113-124. 


\section{Appendix. Glossary of Acronyms}

\begin{tabular}{|c|c|}
\hline $\mathrm{AO}$ & Area of Occupancy \\
\hline ATK & Aboriginal Traditional Knowledge \\
\hline $\mathrm{BB}$ & Baffin Bay \\
\hline COSEWIC & Committee on the Status of Endangered Wildlife in Canada \\
\hline $\mathrm{CS}$ & Cumberland Sound \\
\hline DD & Data Deficient \\
\hline DS & Davis Strait \\
\hline DU & Designated Unit \\
\hline EHA & Eastern High Arctic \\
\hline EN & Endangered \\
\hline $\mathrm{EO}$ & Extent of Occurrence \\
\hline FB & Foxe Basin \\
\hline GB & Gulf of Boothia \\
\hline HA & High Arctic \\
\hline HB & Hudson Bay \\
\hline HBDS & Hudson Bay/Davis Strait \\
\hline $\mathrm{IAO}$ & Index of Area of Occupancy \\
\hline $\mathrm{IK}$ & Inuit Knowledge \\
\hline IKAO & Inuit Knowledge Area of Occupancy \\
\hline IKEO & Inuit Knowledge Extent of Occurrence \\
\hline IUCN & International Union of Conservation of Nature \\
\hline LA & Low Arctic \\
\hline $\mathrm{LS}$ & Lancaster Sound \\
\hline $\mathrm{MC}$ & McClintock Channel \\
\hline NAR & Not At Risk \\
\hline NPC & Nunavut Planning Commission \\
\hline NW & Norwegian Bay \\
\hline NWMB & Nunavut Wildlife Management Board \\
\hline PW & Prince of Wales Island \\
\hline SARA & Species at Risk Act \\
\hline $\mathrm{SC}$ & Special Concern \\
\hline TEK & Traditional Ecological Knowledge \\
\hline TH & Threatened \\
\hline UOM & Use and Occupancy Mapping \\
\hline WHB & Western Hudson Bay \\
\hline WHS & Wildlife Harvest Study \\
\hline
\end{tabular}

